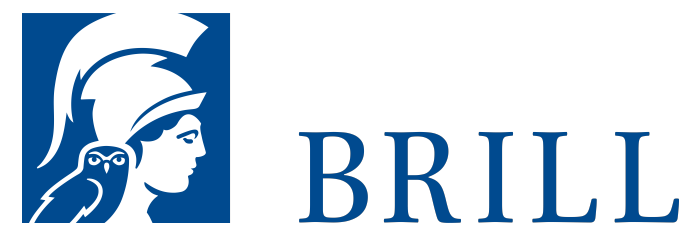

\title{
Eine neue Form von Akademie
}

"Poetik und Hermeneutik" - die Anfänge

Author: Julia Amslinger

Die in den frühen 6oer Jahren gegründete Forschungsgruppe

Poetik und Hermeneutik hat maßgeblichen Anteil an der intellectual history der Bundesrepublik. Das vorliegende Buch ist die erste wissenschaftsgeschichtliche Monographie zu dieser bemerkenswerten >Akademie $<$. Hans Robert Jauß, Hans Blumenberg und Clemens Heselhaus - allesamt ordentliche Professoren für Romanistik, Philosophie und Germanistik in Gießen - luden im Sommer 1963, achtzehn Jahre nach dem Ende der nationalsozialistischen Diktatur einen Kreis von zwanzig Personen zu einem Kolloquium der besonderen Art an ihre Universität: dem ersten Treffen der Gruppe Poetik und Hermeneutik. Das vorliegende Buch beschreibt entlang der Nachlässe von Hans Blumenberg, Hans Robert Jauß und anderer Teilnehmer die Anfangsphase der Forschungsgruppe. Der Traum einer forschenden Gemeinschaft wurde unter Ausschöpfung intellektueller, finanzieller, theoretischer, bürokratischer und medientechnischer Mittel in die Tat umgesetzt und gestaltete sich dann in der Realität gänzlich anders als geplant.

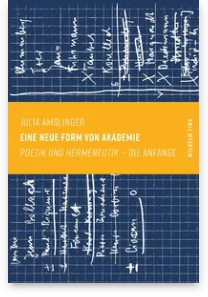

Pages: 386

Seiten, $7 \mathrm{~s} / \mathrm{w}$

Abb.

Language:

German

Subjects:

Cultural History,

Literature and

Cultural Studies

Publisher: Brill |

Fink

E-Book (PDF)

Released online:

04 Sep 2017

ISBN: 978-3-

8467-5384-2

List price

Paperback

Publication date:

14 Jul 2017

ISBN: $978-3^{-}$

7705-5384-6

List price 
Julia Amslinger promovierte 2013 an der Humboldt Universität Berlin. Derzeit arbeitet sie als Mitarbeiterin von Jörg Wesche an der Universität Duisburg-Essen an einer Habilitation über Bindetechniken der Rede in deutschen Verspoetiken des 17. und 18 Jahrhunderts.

For more information see brill.com

Order information: Order online at brill.com +44330 333 o049 | customerservices@brill.com Submission information: brill.com/authors

Titles published by Brill | Fink, Brill | mentis or Brill | Schöningh: +49(o)71 5413279216 | brill@brocom.de 